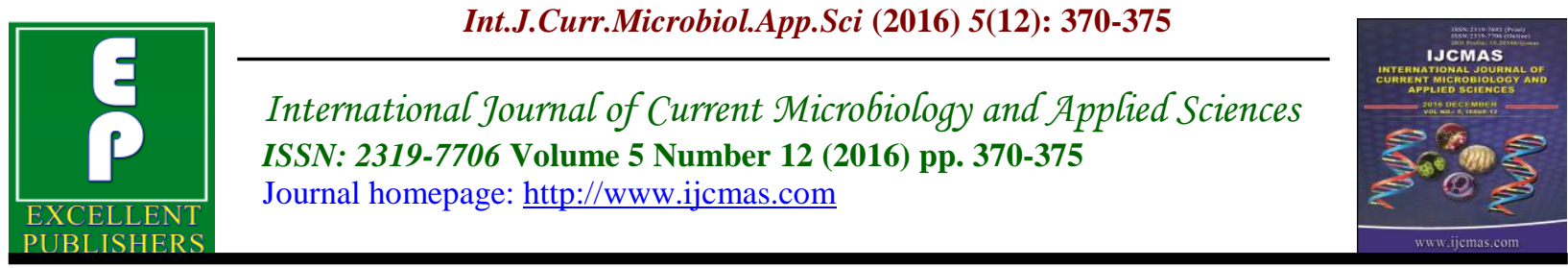

Original Research Article

http://dx.doi.org/10.20546/ijcmas.2016.512.040

\title{
Microbiological Flora and Proximate Composition of the Yam Beetle, Heteroligus meles
}

\author{
E.N. Amadi ${ }^{*}$, D.B. Kiin-Kabari ${ }^{2}$, D.P. William-West ${ }^{1}$ and G.E. Pepple $^{1}$ \\ ${ }^{1}$ Department of Microbiology, ${ }^{2}$ Department of Food Science and Technology, Rivers State \\ University of Science and Technology, Nkpolu-Oroworukwo, Port Harcourt, Nigeria \\ *Corresponding author
}

\begin{tabular}{|c|c|}
\hline & B S T R A C T \\
\hline $\begin{array}{l}\text { Ke y w o r d s } \\
\text { Microbiological } \\
\text { flora, } \\
\text { proximate } \\
\text { composition, yam } \\
\text { beetle (Heteroligus } \\
\text { meles). }\end{array}$ & \multirow{2}{*}{$\begin{array}{l}\text { The microbial flora and proximate composition of whole and wingless yam beetle, } \\
\text { Heteroligus meles, were examined. The heterotrophic bacterial, fungal and } \\
\text { coliform counts of the external surface of the whole beetle were } 6.30 \times 10^{5} \mathrm{cfu} / \mathrm{g} \text {, } \\
2.65 \times 10^{3} \mathrm{cfu} / \mathrm{g} \text { and } 2.65 \times 10^{3} \mathrm{cfu} / \mathrm{g} \text {, respectively. The bacterial species isolated } \\
\text { belonged to the genera, Arthrobacter, Bacillus and Staphylococcus while the fungi } \\
\text { were mainly Aspergillus sp and Cryptococcus sp. These microbial genera constitute } \\
\text { part of the normal soil micro-biota and do not pose a sanitary or health problem. } \\
\text { The proximate composition revealed low moisture content }(57.30 \%) \text { followed by } \\
\text { crude protein at } 23.60 \% \text {, fat at } 12.48 \% \text { and fibre at } 4.44 \% \text {. The values for the } \\
\text { wingless insect followed a similar trend but higher except for ash, fibre and } \\
\text { carbohydrate. The low microbial count coupled with the low moisture content } \\
\text { would assist in the keeping quality of the insect. }\end{array}$} \\
\hline $\begin{array}{l}\text { Article Info } \\
\text { Accepted: } \\
\text { 18 November } 2016 \\
\text { Available Online: } \\
\text { 10 December } 2016\end{array}$ & \\
\hline
\end{tabular}

\section{Introduction}

Heteroligus meles (Billb) (Coleoptera: Dynastidae) is a serious pest of yams in Nigeria and also edible, especially in the Niger Delta. This important insect is listed in the edible insects of the World by Jongema (2015). However, it is not listed as one of Africa's edible insects by Kelemu et. al., (2015) probably because it is not a popular edible insect in Central, Eastern and Southern Africa. The beetles feed on yam planting material (setts) as well as tubers. The most noticeable effect on yams tubers is holes measuring about $1-2 \mathrm{~cm}$ deep, leading to significant post-harvest losses. The adult beetles are salted and roasted or fried with onions and eaten as snack or as food supplement. It is recognized and known by different ethnic groups in Nigeria, e.g. the Hausas call, it puzuzu, the Igbos, ebe, kpaa by the Ogonis and jejere by the Yorubas.

Insects are rich in nutrients and moisture and therefore provide a favourable environment for microbial growth (Van-Huis, et al., 2013). Amadi and Kiin-Kabari (2016) discussed the factors that influence the presence of microorganisms in foods as well as the need for knowledge of the microbial types. The selection of microbial inactivation, the sanitary condition of the food, packaging and storage technologies 
requires knowledge of the microbial flora of the food material involved. Therefore, knowledge of the microbial load of the insect would assist in the selection of these technologies (Amadi and Kiin-Kabari, 2016).

Some edible insects have nutritional value that can be compared to that of meat and fish while others have higher proportion of proteins, fat and energy value (De-Foliart, 1992). Insects constitute an important source of high quality and easily digestible protein (Ramos-Elorduy, et al., 1997; Collavo et al., 2005, Vogel, 2010). Amadi and Kiin-Kabari (2016) reported that members of the order, Coleoptera, contain protein in the range 22 to $74.35 \%$, fat, 4.17 to $81.6 \%$ and carbohydrate, 0.88 to $33.2 \%$ in addition to other nutrients. Although $H$. meles is a member of the Order, Coleoptera, there is a dearth of information on its microbiological flora and proximate composition. This study is, therefore, undertaken to provide data in these areas.

\section{Materials and Methods}

\section{Materials}

Live beetles were collected from soil in Gio of Tai local Government Area of Rivers State, Nigeria and transported to the laboratory in perforated sterile containers. Average weight of adult beetle was $1.5 \mathrm{~g}$. The beetles were either used immediately or within twenty-four hours after storage in a refrigerator. The media used were Peptone water (Micro Master, India), Nutrient agar (Bio-Tech, UK), MacConkey agar (Titan Bio-Tech, India) and Sabourouds agar (Titan Bio-Tech, India).

Fresh lean meat and chicken were purchased from a local daily market in Port Harcourt, Rivers State, Nigeria.

\section{Bacterial viable counts}

The method used was the 10-fold serial dilution method of Harrigan and McCance (1990). Initial tenfold dilution of whole cricket was performed by adding an appropriate volume of physiological saline to an adult beetle, e.g., $8.5 \mathrm{ml}$ of saline was added to $1.5 \mathrm{~g}$ beetle in a $50 \mathrm{ml}$ conical flask and thoroughly shaken to dislodge bacteria. Subsequent 10-fold dilutions were carried out by adding $1.0 \mathrm{ml}$ of the penultimate dilution to $9.0 \mathrm{ml}$ of fresh diluents. Finally $0.1 \mathrm{ml}$ of an appropriate dilution were placed on dry nutrient agar, evenly spread with a sterile glass spreader an incubated at $30^{\circ} \mathrm{C}$ for $24 \mathrm{~h}$ (Amadi et al., 2005). At the end of incubation, counts were performed for those dilutions which showed count between 30 and 300 colonies (Anon, 1994). Counts were performed in duplicate and averages recorded.

\section{Isolation and identification of isolates}

Representative colonies from the initial 10fold dilution were picked and sub-cultured several times onto nutrient agar until pure isolates/cultures were obtained. Such pure cultures were stored as frozen glycerol suspensions at $-35^{\circ} \mathrm{C}$ (Wellington and Williams, 1978). These frozen glycerol suspensions served as a means for long term storage and as a source for working cultures.

Isolates were identified following the scheme of Cowan and Steel (1966) and Buchanam and Gibbons (1974). The tests employed included catalase test, oxidase test, indole production, methyl-red test, motility and oxidation/fermentation tests for fructose, glucose, lactose, maltose, mannitol and sucrose.

Fungal isolates were identified using macroand micro-morphology. 


\section{Chemical analyses for proximate composition}

Proximate analyses were carried out on wet weight basis for moisture, protein $(\mathrm{N} \mathrm{x}$ 6.25), ash, fibre and fat according to AOAC (2012). Total available carbohydrate was analysed using the difference method of Raghuramulu et al., (1983). All analyses were performed in duplicate and averages taken.

\section{Moisture content}

The moisture content in the sample was determined using an air circulating oven (Gallenkamp, UK). Aluminium moisture cans were weighed and dried in the oven for 25 minutes and transferred to the desiccator to cool. Two grams (2g) of sample were weighed into the cans and the weight of moisture cans plus content noted. The cans were then transferred into the oven and heated to a temperature of $105^{\circ} \mathrm{C}$ for 4 hours. The cans and contents were then removed, placed in the desiccator, allowed to cool and re-weighed. The moisture content was calculated using the formula:

Moisture $(\%)=\frac{\text { weight loss after drying }(\mathrm{g})}{\text { Weight of sample }(\mathrm{g})} \times 100$

\section{Crude protein determination}

The micro-Kjeldahl method was used for the determination of total nitrogen. Thus $0.5 \mathrm{~g}$ of sample was weighed into $300 \mathrm{ml}$ digestion flask. One tablet of Kjeldahl catalyst was added followed by the addition of $10 \mathrm{ml}$ concentrated sulphuric acid. The digest was cooled and transferred into $100 \mathrm{ml}$ volumetric flask and made up to $100 \mathrm{ml}$ mark with distilled water. Ten millilitres of the digest was placed into the microKjeldahl distillation apparatus and neutralized with $10 \mathrm{ml}$ of $40 \%$ sodium hydroxide. The content was then distilled into $25 \mathrm{ml}$ of boric acid/indicator. Finally the ammonium borate complex produced was titrated against $0.05 \mathrm{M}$ sulphuric acid. A blank determination without sample was also carried out. The amount of total nitrogen in the sample was calculated using the formula:

$1 \mathrm{ml} 0.05$ sulphuric acid $=1.4 \mathrm{mg}$ nitrogen .

Nitrogen $(\%)=\underline{\text { titre }(\mathrm{ml})-\text { blank }(\mathrm{ml}) \times 1.4} \times 100$

Crude protein $(\%)=$ nitrogen $(\%)$ X 6.25

Ash

The ash content was of the sample was determined using the muffle furnace (Model SK, China). Porcelain crucibles were washed and dried in the oven after which $1 \mathrm{~g}$ of sample in a crucible was placed in a muffle furnace at $550^{\circ} \mathrm{C}$ for 3 hours. At the end the crucibles were placed in a desiccator to cool and the re-weighed with its contents. The ash content was calculated as follows:

Ash $(\%)=\frac{\text { Weight of ash }(\mathrm{g})}{\text { Weight of sample }} \times 100$

\section{Determination of crude fibre}

Half a gram of moisture-free sample was extracted for three hours with petroleum ether (bp $60-80^{\circ} \mathrm{C}$ ) using a soxhlet apparatus. The fat-free material was placed in a $200 \mathrm{ml}$ beaker and $50 \mathrm{ml}$ of $1.25 \%(\mathrm{v} / \mathrm{v})$ sulphuric acid was added and covered with a watch glass. The content of the beaker was heated gently on a hot plate for 30 minutes (acid hydrolysis). At the end of the acid hydrolysis, the content $f$ the beaker was filtered under vacuum through a buchner funnel fitted with filter paper (Whatman No. 4) and washed with boiling water until the washing was no longer acid to litmus. The residue was washed back into the beaker 
with $1.25 \%$ sodium hydroxide, covered with a watch glass and boiled for 30 minutes. The resultant insoluble material was transferred to a dried pre-weighed ash-less filter paper and washed thoroughly, first with hot water until it is no longer alkaline to litmus and then with $95 \%(\mathrm{v} / \mathrm{v})$ ethanol and finally dried at $105^{\circ} \mathrm{C}$ to a constant weight for one hour. The filter paper and its contents were incinerated to ash at $500^{\circ} \mathrm{C}$ for one hour. The ash was then cooled and weighed. The weight of the ash was subtracted from the increase of weight on the filter paper due to the insoluble material and the difference reported as fibre.

$$
\text { Crude fibre }(\%)=\frac{\mathrm{Wt} \text {. of fibre }}{\mathrm{Wt} \text {. of sample }} 100
$$

\section{Determination of fat}

Fat was extracted using the micro Soxhlet extraction unit. Thus $1 \mathrm{~g}$ of sample was weighed into an extraction thimble, placed in the extractor and fitted to the unit. Fat was extracted with $100 \mathrm{ml}$ petroleum ether (boiling point, $60-80^{\circ} \mathrm{C}$ ) for 5 hours using a reflux condenser.. The extracted fat was transferred to an air circulating oven at $80^{\circ} \mathrm{C}$ for 20 minutes to evaporate the solvent. The flask was then cooled in a desiccator and reweighed. Crude fat was calculated from the equation below:

Crude fat $(\%)=\frac{\text { Weight of extract }(\mathrm{g})}{\text { Weight of sample }(\mathrm{g})} \times 100$

\section{Results and Discussion}

The skin microbial populations for the whole yam beetle were $6.30 \times 10^{5} \mathrm{cfu} / \mathrm{g}$ (total heterotrophs), $1.24 \times 10^{5} \mathrm{cfu} / \mathrm{g}$ (coliforms) and $2.65 \times 10^{3} \mathrm{cfu} / \mathrm{g}$ (fungi). The bacterial species isolated belonged to the genera, Arthrobacter, Bacillus and Staphylococcus while the fungi were mainly Aspergillus sp and Cryptococcus sp. Table1 compares the proximate composition of beetle (full and wingless) with those of chicken and lean meat.

Table.1 Comparison of proximate compositions of Heteroligus meles, chicken and lean meat.

\begin{tabular}{|l|c|c|c|c|c|c|}
\hline \multirow{2}{*}{ Sample } & \multicolumn{6}{|c|}{ Proximate composition (\%) } \\
\cline { 2 - 7 } & Moisture & Ash & Fat & Protein & Fibre & Carbohydrate \\
\hline H.meles (Full beetle) & 57.30 & 1.32 & 12.48 & 23.60 & 4.44 & 0.86 \\
H.meles (Wingless) & 58.71 & 0.84 & 13.27 & 24.24 & 2.38 & 0.56 \\
Chicken & 65.20 & 2.61 & 7.23 & 19.80 & 2.86 & 2.30 \\
Lean meat & 66.40 & 1.10 & 3.80 & 21.71 & 5.57 & 1.42 \\
\hline
\end{tabular}

Thus the yam beetle is moderately rich in protein $(23.60 \%$ and $24.40 \%)$ and higher than chicken and lean meat at $19.80 \%$ and $21.71 \%$, respectively. Moisture content was low for $H$. meles at $57.30 \%$ or $58.71 \%$ as against $65.20 \%$ for chicken and $66.40 \%$ for lean meat. Total carbohydrate was also low at $0.86 \%$ and $0.56 \%$ when compared to chicken at $2.30 \%$ and lean meat at $1.42 \%$, respectively. The fat content of the beetle
$(12.60 \%$ or $13.27 \%)$ was, however, much higher than either chicken $(7.23 \%)$ or lean meat $(3.80 \%)$.

In conclusion, these microbial genera constitute part of the normal soil micro-biota and none is a known food spoilage microorganism. They do not therefore pose a sanitary or health problem. The protein content for this insect is within the range 
reported by Amadi and Kiin-Kabari (2016) for edible members of the order, Coleoptera. The moisture content of $57.30 \%$ (adult beetle) and $58.71 \%$ (wingless) are in fair agreement with the values $56.82 \%$ (adult beetle) and $52.88 \%$ (adult without chitin) reported for Rhynchophorus phoenicis by Amadi et al., (2014). The moisture content of food is generally used as a measure of stability and susceptibility to microbial contamination (Scott, 1980). The low microbial count coupled with the low moisture content would assist in the keeping quality of the insect. Overall, the proximate composition of $H$. meles is in reasonable agreement with that of adult Rhynchophorus phoenicis, a member of the Order, Coleoptera as reported by Amadi et al., (2014).

\section{References}

Amadi, E.N. and Kiin-Kabari, D.B. 2016. Nutritional composition and microbiology of some edible insects commonly eaten in Africa, hurdles and future prospects: A critical review. $J$. Food: Microbiol. Safety \& Hyg., 1(1): 1-7.

Amadi, E.N., Kiin-Kabari, D.B, Kpormon, L.B. and Robinson, V.K.K. 2014. Microbial flora and nutritional composition of adult Palm-wine beetle (Rhynchophorus phoenicis). Int. J. Curr. Microbiol. Appl. Sci., 3(11): 169-192.

Amadi, E.N., Ogbalu, O.K., Barimalaa, I.S. and Pius, M. 2005. Microbiology and nutritional composition of an edible larva (Bunaea alcinoe Stoll) of the Niger Delta. J. Food Safety, 25: $193-$ 197.

Anonymous. 1994. Annual Book of ASTM Standards. Water and environment technology, Vol. II. 02, ASTM, Philadelphia, PA, pp 520-523.
AOAC. 2012. Official Method of Analysis. $19^{\text {th }}$ Edition. Association of Official and Analytical Chemists. Washington DC.

Buchanam, R.E. and Gibbons, N.E. eds. 1974. Bergey's Manual of Determinative Bacteriology. Williams \& Wilkins Company, Baltimore, MD.

Collavo, A., Glew, R.H., Yunk-Sheng, H., Lu-Te, C., Bosse, R. and Paoletti, M.G., 2005. Housecricket smallscale farming. In Ecological implications of minilivestock: potential of insects, rodents, frogs and snails, Edited by Paoletti, M.G., Enfield. N.H.: Science Publisher, pp 519-544.

Cowan, S.T. and Steel, K.J., 1966. Manual for Identification of Medical Bacteria. Cambridge University Press, Cambridge, UK.

De-Foliart, G.R. 1992. Insects as human food. Crop Protection, 11(5): 395-399.

Harrigan, W.F. and McCance, M.E., 1990. Laboratory Methods in Food and Dairy, Microbiology. Academic Press, London.

Jay, J.M., Loessner, M.J., and Golden, D.A., 2005. Modern Food Microbiology $7^{\text {th }}$ Edition. Springer Science, NY.

Jongema, Y. 2015. List of edible insects of the world. Wageningen University, Wageningen. The Netherlands. Available at http://tinyurl.com/mestm6p. Accessed on $8 / 10 / 2015$.

Kelemu, S., Niassy, S., Torto, B., Fiaboe, K., Affognon, H., Tonnang, H., Maniania, N.K., and Ekesi, S. 2015. African edible insects for food and feed: inventory, diversity, commonalities and contribution to food security. J. Insects as Food and Feed, 1(2): 103-119.

Prescott, L.M., Hartley, J.P. and Klein, D.A. 2002. Microbiology $5^{\text {th }}$ Edition, McGraw-Hill Publishing, New York. 
Raghuramulu, N., Nair, M.K. and Kalyansundaram, S., 1983. In A Manual of Laboratory Technique. NIN, KMB, Hyderabad, India

Ramos-Elorduy, J., Pino, J.M. Prado, E.E., Perez, M.A., Otero, J.L. and de Guevara, O.L. 1997. Nutritional value of edible insects from the state of Oaxaca, Mexico. J. Food Compos. Anal., 10(2): 142-157.

Scott, W.S. 1980. Water relation of spoilage microorganisms. Adv. Food Res., 7: 84-127.

Van-Huis, A., Van Itterbeek, J., Klunder, H.,
Mertens, E., Halloran, A., Muir, G. and Vantomme, P. 2013. Edible insects: Future prospects for food and feed security. FAO Forestry Paper 171. Food and Agricultural Organisation of the United Nations, Rome, Italy.

Vogel, G. 2010. For more protein, filet of cricket. Sci., 327(5967): 811.

Wellington, E.M.H. and Williams, S.T. 1978. Preservation of actinomycete inoculum in frozen glycerol. Microbios Lett., 6: 151-157.

\section{How to cite this article:}

Amadi, E.N., D.B. Kiin-Kabari, D.P. William-West and Pepple, G.E. 2016. Microbiological Flora and Proximate Composition of the Yam Beetle, Heteroligus meles. Int.J.Curr.Microbiol.App.Sci. 5(12): 370-375. doi: http://dx.doi.org/10.20546/ijcmas.2016.512.040 